\title{
Classification, fixation techniques, complications and outcomes of femur fractures in dogs and cats: 61 cases (2015-2016)
}

\author{
Renato do Nascimento Libardoni ${ }^{1}$ Diego da Costa ${ }^{2}$ Felipe Barretos Menezes ${ }^{2}$ \\ Lucas Geraldo Cavalli ${ }^{2}$ Luís Fernando Pedrotti ${ }^{2}$ Patrícia Regina Kohlrausch $^{2}$ \\ Bruno Watanabe Minto ${ }^{3}$ Marco Augusto Machado Silva ${ }^{*}$
}

${ }^{1}$ Curso de Medicina Veterinária, Universidade de Passo Fundo (UPF), Campus Passo Fundo, Hospital Veterinário, Passo Fundo, RS, Brasil. ${ }^{2}$ Programa de Residência Integrada em Medicina Veterinária, Universidade de Passo Fundo (UPF), Campus Passo Fundo, Hospital Veterinário, Passo Fundo, RS, Brasil.

${ }^{3}$ Departamento de Clínica e Cirurgia Veterinária, Faculdade de Ciências Agrárias e Veterinárias, Universidade Estadual Paulista, Campus Jaboticabal, Jaboticabal, SP, Brasil.

${ }^{4}$ Escola de Veterinária e Zootecnia, Universidade Federal de Goiás (UFG), 74690-900, Goiás, GO, Brasil. E-mail: silvamam@gmail.com. *Corresponding author.

\begin{abstract}
The aim of this study was to retrospectively evaluate the frequency of femur fractures in dogs and cats in the routine of a school hospital, determining their classification, fixation methods, complications, and outcomes. A total of 61 animals, 50 (82.0\%) dogs and $11(18.0 \%)$ cats, had femoral fractures that were submitted to osteosynthesis. Sixty-two femoral fractures were evaluated. Single fractures in the distal epiphysis $(n=25)$ were the most frequent $(P=0.0001)$. Intramedullary pins were used in association with cerclage and tension band for osteosynthesis in proximal fractures. In diaphyseal fractures, bone plates and screws, two intramedullary pins (insulated or with cerclage) and Tie-In configuration were used. In distal fractures, modified Rush intramedullary pins, cross pins and Tie-In configuration were used. Comparing complication frequencies at fracture sites that required reintervention after osteosynthesis, a significant difference was observed $(P=0.0253)$ between the diaphyseal $(31.25 \%)$ and distal $(7.14 \%)$ fractures independent of the technique used. We concluded that distal epiphyseal fractures were the most frequent in the routine of a school hospital. Distal epiphyseal fractures presented a lower frequency of complications for consolidation when treated with modified Rush intramedullary pins or crossed pins. Key words: small animals, casuistry, retrospective study, distal fractures.
\end{abstract}

Classificação, métodos de fixação, complicações e desfecho das fraturas de fêmur em cães e gatos: 61 casos (2015-2016)

RESUMO: $O$ objetivo deste estudo foi avaliar, retrospectivamente, a frequência das fraturas de fêmur em cães e gatos, na rotina de um hospital escola, determinando a classificação, métodos de fixação, complicações e desfecho. No total, 61 animais, 50 (82,0\%) cães e 11 $(18,0 \%)$ gatos, apresentaram fraturas de fêmur submetidas a osteossintese. Sessenta e duas fraturas de fêmur foram avaliadas neste estudo. As fraturas simples localizadas na epifise distal $(n=25)$ foram as mais frequentes $(P=0,0001)$. Para osteossintese das fraturas proximais, foram utilizados pinos intramedulares em associação a cerclagem e banda de tensão. Nas fraturas diafisárias, foram utilizadas placas ósseas e parafusos, dois pinos intramedulares (isolados ou com cerclagem) e fixador externo Tie-In e, nas fraturas distais, pinos intramedulares de Rush modificados, pinos cruzados e fixador externo Tie-In. Comparando-se a frequência de complicações que necessitaram reintervenção após osteossíntese, entre as localizações das fraturas, independente da técnica empregada, houve uma diferença significativa ( $P=0,0253)$ entre as diafisárias $(31,25 \%)$ e distais $(7,14 \%)$. Conclui-se que as fraturas epifisárias distais foram as mais frequentes na rotina de um hospital escola e, quando tratadas com pinos intramedulares de Rush modificados ou pinos cruzados, apresentaram menor frequência de complicações para a consolidação.

Palavras-chave: pequenos animais, casuística, estudo retrospectivo, fraturas distais.

\section{INTRODUCTION}

Femur fractures are common in dogs and cats, accounting for $20-25 \%$ of all fractures in these animals. These fractures can be classified in many bases, and the classification system adopted by the AO Vet allows alphanumeric evaluation and coding for location, morphology, and severity (DeCAMP et al., 2016). Femur fractures are classified as femoral head, femoral neck, trochanteric, subtrochanteric, diaphyseasl, suprachondillary, or condylar, and distal (JOHNSON, 2013), and they are mostly closed due to the supraskeletal muscles (BEALE, 2004). None of them allows a conservative treatment with external coaptation, due to the anatomical peculiarities of the femur and surrounding soft tissues (BEALE, 2004; DeCAMP et al., 2016).

Thus, a complete understanding of the forces acting on the fracture focus to which implants will be 
submitted is essential to select the implant and fixation technique(BEALE, 2004; JOHNSON, 2013). Treatments are often successful when basic principles of repair are used (BEALE, 2004; DeCAMP et al., 2016). Suitable implants include bone plates and screws, intramedullary pins and cerclages, blocked intramedullary nails and external skeletal fixator, using anatomical reduction and rigid fixation, or biological osteosynthesis. Complications included pin migration, sciatic nerve block, infection, non-union, late union, implant failure, quadriceps muscle contracture, and premature physeal closure, leading to limb shortening or angular deformity (BEALE, 2004; ROUSH, 2005). Therefore, the objective of the present study was to retrospectively evaluate the classification, fixation methods, complications, and outcome of femoral fractures in dogs and cats in the routine of a school hospital.

\section{MATERIALS AND METHODS}

Records of orthopedic services, which were carried out at the Veterinary Hospital (HV), Universidade de Passo Fundo (UPF), in the period Jan 2015 to Dec 2016, were reviewed. Dogs and cats with femur fracture(s) confirmed by previous history, clinical, orthopedic, and radiographic examination, and submitted to osteosynthesis surgical treatment were included in this study. Information about the species, race, age, gender, weight, and causative agent were recorded, and the animals were distributed into four age groups: puppies (less than 1 year), young adult (1-3 years), mature adult (3-10 years), and elderly (over 10 years old), according to the methodology used in another case study (SHEARER, 2011). Regarding size (weight), the dogs were categorized in: less than $6 \mathrm{~kg}, 6-15 \mathrm{~kg}, 15-25 \mathrm{~kg}$, and more than $25 \mathrm{~kg}$. Cats were categorized in: less than $2 \mathrm{~kg}, 2-3 \mathrm{~kg}, 3-4 \mathrm{~kg}$, and $4-5 \mathrm{~kg}$.

Regarding location, morphology, and severity of fractures in long bones, the fractures were classified based on the classification system adopted by the AO Vet (DeCAMP et al., 2016). Fracture site was obtained assigning number 3 to each femur bone, and dividing it into the 1 (proximal), 2 (diaphyseal), and 3 (distal) zones. For severity, each fracture was classified as A (simple fracture), B (multiple fracture/reducible wedge), and $\mathrm{C}$ (comminuted fracture/non-reducible wedge). Subsequently, each evaluation was grouped into 1 (slight), 2 (moderate), or 3 (severe), depending on the type and extent of bone fragmentation. For fractures in the proximal and distal bone zones, a second individual description was performed to designate the specific morphology. The fixation methods were evaluated through the classification and severity of the cases. Data on the evaluations performed in the post-surgical period were collected, with emphasis on the complications reported, reinterventions, and final outcome. Complications were categorized into minor, major, and catastrophic. Catastrophic complications were those that resulted in an unacceptable permanent functioning of the limb, resulting in amputation. Major complications required surgical treatment for resolution. Minor complications did not require additional surgical or medical treatment for resolution (COOK et al., 2010).

Frequencies of bone consolidation and major complications were compared using the Fisher's exact test, with view to the osteosynthesis techniques and anatomical (proximal, diaphyseal, and distal) locations, independent of the technique used. The G-Test was used for comparison between fracture types as a function of their location. Other epidemiological data were analyzed using descriptive statistics. For all tests, the $5 \%$ significance level was adopted.

\section{RESULTS AND DISCUSSION}

A total of 61 animals, $50(82.0 \%)$ dogs and $11(18.0 \%)$ cats, presented fractures in the femur bone, which underwent osteosynthesis. In our sample, part of dogs $(48.0 \%)$ and cats $(90.9 \%)$ had an undefined breed. Dogs had defined breeds such as Australian Cattle Dogs (2; 4.0\%), Border Collies (2; 4.0\%), Boxers (2; 4.0\%), Poodles $(2 ; 4.0 \%)$, Pinschers $(3 ; 6.0 \%)$, Shih Tzus (4; $8.0 \%)$, and other breeds $(11 ; 22.0 \%)$. Only one $(9.1 \%)$ cat was of the Siamese breed. Regarding age group, dogs were pups $(28 ; 48.0 \%)$, young adults $(12 ; 24.0 \%)$, mature adults $(7 ; 14.0 \%)$, and old dogs $(3 ; 6.0 \%)$. Cats were puppies $(8 ; 72.7 \%)$ and young adults $(3 ; 27.3 \%)$. As for gender, femoral fractures in male dogs $(30 ; 60 \%)$ were more frequent than in female dogs $(20 ; 40.0 \%)$; similarly, such fractures in male cats $(8 ; 72.7 \%)$ were also more frequent than in female cats $(3 ; 27.3 \%)$.

In this study, puppies were most affected by femoral fractures due to low bone density in their development (osteogenesis) phase. At this stage, these bones are fragile even for minor trauma (MINAR, 2013) and due to lack of ability of the puppies to avoid trauma (VIDANE, 2014). Such fractures occur more frequently in the proximal or distal physes, whereas metaphyseal and diaphyseal fractures are more common in mature patients (BEALE, 2004; KIM et al., 2012).

Regarding animal size, dog weights were less than $6 \mathrm{~kg}(21 ; 42.0 \%)$, between $6-15 \mathrm{~kg}(20 ; 40.0 \%)$, and $15-25 \mathrm{~kg}(8 ; 16.0 \%)$, and greater than $25 \mathrm{~kg}(1 ; 2.0 \%)$. Cat weights were less than $2 \mathrm{~kg}(2 ; 18.2 \%)$, between $2-3 \mathrm{~kg} \mathrm{(}$; $27.3 \%), 3-4 \mathrm{~kg}(5 ; 45.4 \%)$, and $4-5 \mathrm{~kg}(1 ; 9.1 \%)$. As for etiology, car accidents were the main cause (45 dogs; 3 cats), followed by falls ( 2 dogs; 4 cats), dog bite ( 1 dog; 
3 cats), treadmill (1 cat), human aggression (1 dog), and ballistic projectile ( $1 \mathrm{dog})$. In this study, car accidents and falls were the most frequent causes of femoral fractures in dogs and cats, respectively. Traumatic events are the main cause of orthopedic disorders in dogs and cats(STREETER et al., 2009; ELZOMOR et al., 2014), and fractures result mainly from car accidents (VIDANE, 2014), ballistic projectiles, fights, and falls (KUMAR, 2007). High incidence of car accidents was due to the high number of both animals with access to public roads, and owners who suppress the containment and protection measures in their homes and during outings (LIBARDONI et al., 2016).

In this study, 62 femoral fractures were evaluated (Table 1). The simpler and more complex proximal, diaphyseal, and distal fractures were "3 $1 \mathrm{~A} 1$ " (n=1), "3 $1 \mathrm{C} 1$ " (n=1), "3 2 A1" (n=11), "3 2 C3" (n=1), "3 3 A1" (n=24), and "3 3 C2" $(n=2)$, respectively. In the comparison between fracture morphology and bone zone (Table 2)simple fractures in the distal epiphysis $(n=25)$ were most frequent $(\mathrm{P}=0.0001)$. Distal fractures were individually described as Salter-Harris type I $(n=7)$, Salter-Harris type II $(n=13)$, Salter-Harris type III $(n=1)$, metaphyseal extra-articular fracture $(n=6)$, and partial joint fracture $(n=1)$. We emphasized that fragment exposure occurred in three of the fractures mentioned above. Only two proximal fractures occurred (major trochanter avulsion and metaphyseal extra joint fracture), both in dogs.
A careful evaluation of femoral fractures is of paramount importance in order to adequately plan the treatment (BEALE, 2004; ROUSH, 2005). In the present study, the classification system adopted by the AO Vet (DeCAMP et al., 2016) allowed to evaluate and alphanumerically codify fractures in terms of location, morphology, and severity, thus facilitating fracture complexity determination and its subsequent evaluation regarding appropriate treatment and prognosis. In this study, nine internal fixation methods were used for primary bone repair (Table 3) Lateral access to the thigh was performed to reduce the proximal and diaphyseal fractures, with separation of the biceps femoris and vastus lateralis quadriceps muscles from each other. Lateral arthrotomy was performed in dogs (weight $\leq 15 \mathrm{~kg}$ ) and cats, and medial arthrotomy was performed in dogs (weight $>15 \mathrm{~kg}$ ) to reduce distal fractures. Intramedullary pins were used in proximal fractures in association with cerclage $(n=1)$ for reduction of the subtrochanteric fracture, and tension band $(n=1)$ for avulsion of the greater trochanter. Bone plates and screws were used for treatment of diaphyseal fractures (compressive function, $\mathrm{n}=1$; neutral function after interfragmentary compression, with cerclage, $\mathrm{n}=1$; and, bridge function, associated with the use of intramedullary pin, $n=6$ ), two intramedullary pins to fill $85 \%$ of the medullary

Table 1 - Alphanumeric morphological classification of fractures, according to location, morphology, and severity, in dogs and cats attended in a hospital school (January 2015 to December 2016).

\begin{tabular}{|c|c|c|c|c|c|c|}
\hline \multicolumn{2}{|c|}{---------Location------- } & \multicolumn{2}{|c|}{--------------------Morphology---------------- } & \multirow{2}{*}{$\begin{array}{l}\text { Dogs } \\
\text { n (\%) }\end{array}$} & \multirow{2}{*}{$\begin{array}{c}\text { Cats } \\
\text { n (\%) }\end{array}$} & \multirow{2}{*}{$\begin{array}{l}\text { Total } \\
\mathrm{n}(\%)\end{array}$} \\
\hline Bone & Zones & Severity & Complexity & & & \\
\hline 3 & 1 & A & 1 & $1(1.6)$ & $0(0)$ & $1(1.6)$ \\
\hline 3 & 1 & $\mathrm{C}$ & 1 & $1(1.6)$ & $0(0)$ & $1(1.6)$ \\
\hline \multicolumn{4}{|c|}{ 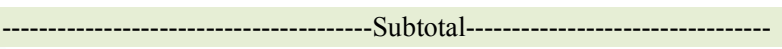 } & $2(3.2)$ & $0(0)$ & $2(3.2)$ \\
\hline 3 & 2 & A & 1 & $9(14.5)$ & $2(3.2)$ & $11(17.7)$ \\
\hline 3 & 2 & B & 1 & $10(16.1)$ & $1(1.6)$ & $11(17.7)$ \\
\hline 3 & 2 & $\mathrm{~B}$ & 2 & $2(3.2)$ & $2(3.2)$ & $4(6.4)$ \\
\hline 3 & 2 & $\mathrm{C}$ & 1 & $2(3.2)$ & $0(0)$ & $2(3.2)$ \\
\hline 3 & 2 & $\mathrm{C}$ & 2 & $1(1.6)$ & $2(3.2)$ & $3(4.8)$ \\
\hline 3 & 2 & $\mathrm{C}$ & 3 & $1(1.6)$ & $0(0)$ & $1(1.6)$ \\
\hline \multicolumn{4}{|c|}{-------------------------------------------Subtotal----------------------------------- } & $25(40.3)$ & $7(11.3)$ & $32(51.6)$ \\
\hline 3 & 3 & A & 1 & $21(33.9)$ & $3(4.8)$ & $24(38.7)$ \\
\hline 3 & 3 & A & 2 & $0(0)$ & $1(1.6)$ & $1(1.6)$ \\
\hline 3 & 3 & $\mathrm{C}$ & 1 & $1(1.6)$ & $0(0)$ & $1(1.6)$ \\
\hline 3 & 3 & $\mathrm{C}$ & 2 & $2(3.2)$ & $0(0)$ & $2(3.2)$ \\
\hline \multicolumn{4}{|c|}{ 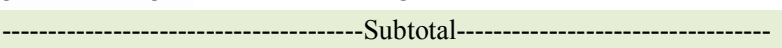 } & $24(38.7)$ & $4(6.4)$ & $28(45.2)$ \\
\hline \multicolumn{4}{|c|}{-------------------------------------------- Total----------------------------------- } & $51(82.3)$ & $11(17.7)$ & $62(100)$ \\
\hline
\end{tabular}

Ciência Rural, v.48, n.6, 2018. 
Table 2 - Comparison between fracture morphology and the bone zone using the $\mathrm{G}$ Test $(\mathrm{P}<0.05)$ in dogs and cats attended in a hospital school (January 2015 to December 2016).

\begin{tabular}{|c|c|c|c|c|}
\hline \multirow{2}{*}{ Bone areas } & \multicolumn{3}{|c|}{---------------------------------------------Fracture morphology-------------------------------- } & \multirow{2}{*}{ Total n $(\%)$} \\
\hline & Simplen $(\%)$ & Multiplen (\%) & Cominutiven $(\%)$ & \\
\hline Proximal & $1(1.6)$ & 0() & $1(1.6)$ & $2(3.2)$ \\
\hline Diaphyseal & $11(17.7)$ & $15(24.2)$ & $6(9.7)$ & $32(51.6)$ \\
\hline Distal & $25(40.3)$ & $0(0)$ & $3(4.8)$ & $28(45.2)$ \\
\hline Total & $37(59.7)$ & $15(24.2)$ & $10(16.1)$ & $62(100)$ \\
\hline \multirow{2}{*}{ G-Test } & Value & GL & $P$ & \\
\hline & 28.1 & 4 & 0.0001 & \\
\hline
\end{tabular}

canal (isolated, $\mathrm{n}=5$; or associated with the use of cerclage, $n=14$ ) and external skeletal fixator Tie-In configuration $(n=5)$ (association of an intramedullary pin and type-IA external skeletal fixator). Animals with distal fractures were treated using the modified Rush intramedullary pin technique $(\mathrm{n}=11)$, cross-pin technique $(n=14)$, and Tie-In configuration $(n=3)$. In relation to the internal fixation methods used in this study, each implant was evaluated in terms of its advantages and disadvantages. However, determining the "best" fixation method was impossible, due to variability in patients, injuries, expertise, equipment, and finance. Nevertheless, his selection was based on age, weight, and characteristics of fracture. The fixation combinations were considered, being an intramedullary pin with external skeletal fastener, an intramedullary pin with bone plate, and modified or crossed Rush pins (HARARI, 2002; BEALE, 2004; ROUSH, 2005; DeCAMP et al., 2016).
Complications $(n=14)$ were observed (Table 4) and categorized into minor $(n=4)$ and major $(n=10)$ complications. Catastrophic complications were not observed. Complication frequencies for fracture sites that required reintervention after osteosynthesis were compared and a significant difference $(\mathrm{P}=0.0253)$ was observed between the diaphyseal (31.25\%) and distal (7.14\%) fractures independent of the technique employed. In addition, a low frequency $(n=2)$ of proximal fractures was observed in this study. One of them $(50 \%)$ was treated with tension band and resulted in bone consolidation without complication; the other $(50 \%)$, which was treated with osteosynthesis, intramedullary pin, and cerclage, resulted in pin migration and need for reintervention for consolidation where the pins were cut and buried.

Table 3 - Frequency of osteosynthesis methods in relation to fracture morphology in dogs and cats attended in a hospital school (January 2015 to December 2016).

\begin{tabular}{|c|c|c|c|c|}
\hline \multirow{2}{*}{ Osteosynthesis methods } & \multicolumn{3}{|c|}{ 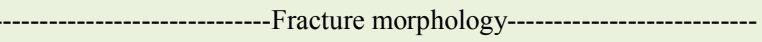 } & \multirow{2}{*}{ Total n $(\%)$} \\
\hline & Simple n $(\%)$ & Multiple n (\%) & Cominutive $\mathrm{n}(\%)$ & \\
\hline Tension band & $1(1.6)$ & $0(0)$ & $0(0)$ & $1(1.6)$ \\
\hline DCP & $1(1.6)$ & $0(0)$ & $0(0)$ & $1(1.6)$ \\
\hline Tie-In configuration & $1(1.6)$ & $2(3.2)$ & $5(8.1)$ & $8(12.9)$ \\
\hline IMP & $5(8.1)$ & $0(0)$ & $0(0)$ & $5(8.1)$ \\
\hline IMP + cerclage & $5(8.1)$ & $8(12.9)$ & $2(3.2)$ & $15(24.2)$ \\
\hline Cross pins & $14(22.6)$ & $0(0)$ & $0(0)$ & $14(22.6)$ \\
\hline Modified Rush pins & $10(16.1)$ & $1 *(1.6)$ & $0(0)$ & $11(17.7)$ \\
\hline $\mathrm{NP}+$ cerclage & $0(0)$ & $1(1.6)$ & $0(0)$ & $1(1.6)$ \\
\hline $\mathrm{BP}+\mathrm{IMP}$ & $0(0)$ & $3(4.8)$ & $3(4.8)$ & $6(9.7)$ \\
\hline Total & $37(54.2)$ & $15(18.1)$ & $10(8.3)$ & $62(100)$ \\
\hline
\end{tabular}

DCP: Dynamic compression plate; IMP: Intramedullary pin; NP: Neutral plate; BP: Bridge plate. * Modified Rush pins associated with cerclage. 
Classification, fixation techniques, complications and outcomes of femur fractures in dogs and cats: 61 cases (2015-2016)

Table 4 - Frequency of complications in relation to osteosynthesis methods in dogs and cats attended in a hospital school (January 2015 to December 2016).

\begin{tabular}{|c|c|c|c|c|}
\hline \multirow{2}{*}{ Osteosynthesis methods } & \multirow[b]{2}{*}{ Minor n (\%) } & \multirow[b]{2}{*}{ Major n (\%) } & \multirow{2}{*}{ Catastrophic n $(\%)$} & \multirow[b]{2}{*}{ Absent n $(\%)$} \\
\hline & & & & \\
\hline Tension band & $0(0)$ & $0(0)$ & $0(0)$ & $1(1.6)$ \\
\hline DCP & $0(0)$ & $0(0)$ & $0(0)$ & $1(1.6)$ \\
\hline Tie-In configuration & $4(6.4)$ & $2(3.2)$ & $0(0)$ & $2(3.2)$ \\
\hline IMP & $0(0)$ & $2(3.2)$ & $0(0)$ & $3(4.8)$ \\
\hline $\mathrm{IMP}+$ cerclage & $0(0)$ & $2(3.2)$ & $0(0)$ & $13(21.0)$ \\
\hline Cross pins & $0(0)$ & $0(0)$ & $0(0)$ & $14(22.6)$ \\
\hline Modified Rush pins & $0(0)$ & $2(3.2)$ & $0(0)$ & $9(14.5)$ \\
\hline $\mathrm{NP}+$ cerclage & $0(0)$ & $1(1.6)$ & $0(0)$ & $0(0)$ \\
\hline $\mathrm{BP}+\mathrm{IMP}$ & $0(0)$ & $1(1.6)$ & $0(0)$ & $5(8.1)$ \\
\hline Total & $4(6.4)$ & $10(16.1)$ & $0(0)$ & $48(77.4)$ \\
\hline
\end{tabular}

DCP: Dynamic compression plate; IMP: Intramedullary pin; NP: Neutral plate; BP: Bridge plate.

Migration of intramedullary pins was observed in diaphyseal fractures $(n=4)$, causing fragmentation in the fracture focus and requiring surgical reintervention for consolidation. Migration of modified Rush intramedullary pins occurred in two cases, being related to a delayed union in one of the cases. Loosening of pins in the external skeletal fixator and secretion drainage through the path of the pins were observed in four cases. This was attributed to the choice of an inadequate pin diameter $(\mathrm{n}=2)$, exuberant muscular mass of the thigh $(n=1)$, and rapid growth of the puppy $(n=1)$. Due to small pin diameter, a case of non-union and another of delayed union occurred. In one case, migration of fixation screws was observed in the bridging plate due to fall of a female patient in the postoperative period. Another case of folding of the plate in neutral function was also observed, causing fragmentation in the fracture focus, due to the occurrence of a new trauma. In our opinion; however, most of these complications could have been prevented by better surgical planning, use of the basic repair principles, appropriate selection of implants, and differentiated postoperative management, thus confirming previous observations (BEALE, 2004; ROUSH, 2005; McCARTNEY \& MacDONALD, 2006; VALLEFUOCO, 2016).

In general, the use of modified Rush intramedullary pins and crossed pins in this study were the most successful methods for the consolidation of femoral fractures. However, the most fragmented fractures were repaired with the use of bridging plate associated with the intramedullary pin, external skeletal fixator Tie-In configuration, and association of intramedullary pins with cerclage. Therefore, stating that the complication rate is due to the attachment method, fracture, and patient characteristics is impossible (JACKSON \& PACCHIANA, 2004; KÖNNING, 2013).

However, it was observed that fractures treated with the external skeletal fixator TieIn configuration presented a greater number of complications. In addition, given the low number of cases per fixation method employed, statistical comparison between different types of implants did not allow us to support this perception. In this study, a positive correlation was observed between juvenility and rate of consolidation without complications, because distal fractures consolidated with a lower index of complication after osteosynthesis independent of the technique used. Bones of young animals tend to heal faster than those of older animals (STRUBE, 2008) because many arteries perforate the newly formed appositional bone, running longitudinally over the periosteal surface (JOHNSON, 2013).

\section{CONCLUSION}

Distal epiphyseal fractures of the femur were the most frequent in the routine of a school hospital. These fractures presented a lower frequency of complications for consolidation when treated with either modified Rush intramedullary pins or cross pins.

\section{ACKNOWLEDGEMENTS}

The authors are grateful to the Integrated Residency Program in Veterinary Medicine of the University of Passo Fundo, RS, Brazil. 


\section{DECLARATION OF CONFLICTS OF INTEREST}

The authors declared no potential conflicts of interest with respect to the research, authorship, and/or publication of this article.

\section{REFERENCES}

BEALE, B. Orthopedic clinical techniques femur fracture repair. Clinical Techniques in Small Animal Practice, v.19, n.3, p.134-150, 2004. Available from: $<$ https://www.sciencedirect.com/science/article/ pii/S109628670400057X>. Accessed: Nov. 13, 2016. doi: 10.1053/j. ctsap.2004.09.006

COOK, J.L. Proposed definitions and criteria for reporting time frame, outcome, and complications for clinical orthopedic studies in Veterinary Medicine. Veterinary Surgery, v.39, n.8, p.905908, 2010. Available from: <https://onlinelibrary.wiley.com/doi/ abs/10.1111/j.1532-950X.2010.00763.x>. Accessed: Nov. 13, 2016 doi: 10.1111/j.1532-950X.2010.00763.x.

DeCAMP, C.E. et al. Brinker, Piermattei and Flo's Handbook of Small Animal Orthopedics and Fracture Repair. 5th edn. St. Louis, Missouri: Saunders Elsevier, 2016. 868p.

ELZOMOR, S.T. et al. Prevalence of femoral fractures in dogs and cats. Journal of the Egyptian Veterinary Medical Association, v.74, n.2, p. 269-278, 2014. Available from: <https://pdfs semanticscholar.org/c75a/21a0fdc3035be90d1b6021df8457f65e4 2c2.pdf>. Accessed: Nov. 13, 2016

HARARI, J. Treatments for feline long bone fractures. The Veterinary Clinics Small Animal Practice, v.32, n.4, p.927-947, 2002. Available from: $<$ https://www.ncbi.nlm.nih.gov/pubmed/12148319>. Accessed: Nov. 13, 2016.

JACKSON, L.C.; PACCHIANA, P.D. Common complications of fracture repair. Clinical Techniques in Small Animal Practice, v.19, n.3, p.168-179, 2004. Available from: <https://www.sciencedirect. com/science/article/pii/S1096286704000593>. Accessed: Nov. 13, 2016. doi: 10.1053/j.ctsap.2004.09.008.

JOHNSON, A.L. Management of specific fractures. In: FOSSUM, T.W. Small animal surgery. 4th.ed. St. Louis, Missouri: Mosby Elsevier, 2013. p.1106-1214

KIM, S.E. et al. Percutaneous pinning for fracture repair in dogs and cats. Veterinary Clinics of North America: Small Animal Practice, v.42, n.5, p.963-974, 2012. Available from: $<$ https://www.vetsmall. theclinics.com/article/S0195-5616(12)00109-X/abstract $>$. Accessed: Nov. 13, 2016. doi: 10.1016/j.cvsm.2012.07.002.

KÖNNING, T. et al. A comparison between fixation methods of femoral diaphyseal fractures in cats - a retrospective study. Journal of Small Animal Practice, v.54, n.5, p.248-252, 2013. Available from: $<$ https://www.ncbi.nlm.nih.gov/pubmed/23560936>. Accessed: Nov. 13, 2016. doi: 10.1111/jsap.12061.
KUMAR, K. et al. Occurrence and pattern of long bone fractures in growing dogs with normal and osteopenic bones. Journal of Veterinary Medicine Series A, v.54, n.9, p.484-490, 2007. Available from: <https:// www.ncbi.nlm.nih.gov/pubmed/17931221>. Accessed: Nov. 13, 2016. doi: 10.1111/j.1439-0442.2007.00969.x.

LIBARDONI, R.L. et al. Appendicular fractures of traumatic etiology in dogs: 955 cases (2004-2013). Ciência Rural, v.46, n.3, p.542-546, 2016. Available from: <http://www.scielo.br/ scielo.php?script $=$ sci arttext\&pid $=\mathrm{S} 0103-84782016000300542>$. Accessed: Feb. 02, 2016. doi: 10.1590/0103-8478cr20150219.

McCARTNEY, W.T.; MacDONALD, B.J. Incidence of non-union in long bone fractures in 233 cats. International Journal of Applied Research in Veterinary Medicine, v.4, n.3, p.209-212, 2006. Available from: <https://pdfs.semanticscholar.org/5656/5e01f435d a26bdb52132344cb6f81eb35356.pdf>. Accessed: Nov. 13, 2016.

MINAR, M. et al. Retrospective study on fractures in dogs. Journal Biomedical Research, v.14, n.3, p.140-144, 2013. Available from: <https://www.researchgate.net/profile/Maruf Minar/ publication/266618235_Retrospective_study_on_fractures_in_dogs/ links/5435ef3c0cf2bf1f1 f2b55e1/Retrospective-study-on-fracturesin-dogs.pdf>.Accessed:Nov.13,2016.doi:10.12729/jbr.2013.14.3.140.

ROUSH, J.K. Management of fractures in small animals. Veterinary Clinics of North America: Small Animal Practice, v.35, n.5, p.1137-1154, 2005. Available from: <https://www.vetsmall. theclinics.com/article/S0195-5616(05)00086-0/fulltext?code $=$ vspsite>. Accessed: Nov. 13, 2016. doi: 10.1016/j.cvsm.2005.06.001.

SHEARER, Epidemiology of orthopedic disease. Veterinary Focus, v.21, n.2, p. 24-25, 2011. Available from: $<$ http://www.ivis. org/journals/vetfocus/21_2/en/toc.asp>. Accessed: Nov. 13, 2016.

STREETER, E.M. Evaluation of vehicular trauma in dogs: 239 cases (January-December 2001). Journal of the American Veterinary Medical Association, v.235, n.4, p.405-408, 2009. Available from: <https://www.ncbi.nlm.nih.gov/pubmed/19681722>. Accessed: Nov. 13, 2016. doi: 10.2460/javma.235.4.405.

STRUBE, P. etal. Influence of age and mechanical stability on bone defect healing: age reverse mechanical effects. Bone, v.42, n.4, p.758-764, 2008. Available from: <https://www.ncbi.nlm.nih.gov/pubmed/18280233>. Accessed: Nov. 13, 2016. doi: 10.1016/j.bone.2007.12.223.

VALLEFUOCO, R. et al. Complications of appendicular fracture repair in cats and small dogs using locking compression plates. Veterinary and Comparative Orthopaedics Traumatoly, v.29, n.1, p.46-52, 2016. Available from: <https://www.ncbi.nlm.nih.gov/pubmed/26511152>. Accessed: Nov. 13, 2016. doi: 10.3415/VCOT-14-09-0146.

VIDANE, A.S. et al. Incidence of fractures in the dogs and cats in Maputo (Mozambique) between 1998 and 2008. Ciência Animal Brasileira, v.15, n.4, p.490-494, 2014. Available from: $\quad<$ http://www.scielo.br/scielo.php?script=sci arttext\&pid=S1809-68912014000400015>. Accessed: Nov. 13, 2016. doi: 10.1590/1089-6891v15i424279. 